\title{
Pengaruh Moralitas Individu, Komitmen Organisasi dan Kesesuaian Kompensasi pada Kecurangan Akuntansi
}

\author{
Ni Luh Putu Eka Suarniti ${ }^{1}$ \\ Fakultas Ekonomi dan Bisnis \\ Universitas Udayana, Indonesia \\ Email: ekasuarniti47@gmail.com
}

\author{
Maria Mediatrix Ratna Sari ${ }^{2}$ \\ Fakultas Ekonomi dan Bisnis \\ Universitas Udayana, Indonesia
}

\begin{abstract}
ABSTRAK
Kecurangan akuntansi merupakan tindakan yang dilakukan akibat adanya keinginan atau dorongan untuk memanfaatkan kesempatan sehingga dapat melakukan manipulasi akuntansi pada laporan keuangan, korupsi atau penyalahgunaan aset. Penelitian bertujuan untuk mengetahui pengaruh moralitas individu, komitmen organisasi dan kesesuaian kompensasi pada kecurangan akuntansi di LPD se-Kecamatan Mengwi. Metode penentuan sampel yang digunakan yaitu menggunakan teknik purposive sampling dengan dua kriteria. Metode pengumpulan data dilakukan dengan menggunakan kuesioner dan kuesioner yang kembali berjumlah 194 kuesioner. Teknik analisis data yang digunakan yaitu analisis regresi linear berganda. Berdasarkan hasil uji yang dilakukan diperoleh hasil yaitu moralitas individu komitmen organisasi dan kesesuaian kompensasi berpengaruh negatif pada kecurangan akuntansi.
\end{abstract}

Kata Kunci: Moralitas Individu; Komitmen Organisasi; Kesesuaian Kompensasi; Kecurangan Akuntansi.

\section{The Influence of Individual Morality, Organizational Commitment and Compensation Conformity on Accounting Fraud}

\begin{abstract}
Accounting fraud is an action due to the desire or encouragement to use the opportunity so as to manipulate accounting of financial statements, corruption or misappropriation of assets. Research aims to determine the influence of individual morality, organizational commitment and conformity of compensation on accounting fraud in the LPD of Mengwi sub-district. The sampling method is using the purposive sampling technique. The data collection method is permormed using questionnaires and questionnaires returned are 194 questionnaires. The data analysis technique used is multiple linear regression. Based on the results of the tests, individual morality, organizational commitment and compensation conformity have negative affect on accounting fraud.
\end{abstract}

Keywords: Individual Morality; Organizational Commitment; Compensation Conformity; Accounting Fraud.

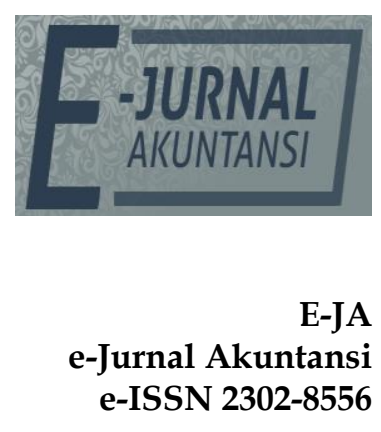

Vol. 30 No. 2 Denpasar, Februari 2020

Hal. 319-333

Artikel Masuk: 12 Desember 2019

Tanggal Diterima: 16 Januari 2020 


\section{PENDAHULUAN}

Kecurangan akuntansi adalah upaya atau tindakan yang dilakukan secara sengaja akibat adanya kesempatan atau dorongan tertentu dengan melakukan manipulasi akuntansi pada laporan keuangan, korupsi atau penyalahgunaan aset yang berdampak buruk bagi keberlanjutan entitas. Kecurangan akuntansi dalam organisasi akan menimbulkan data laporan keuangan perusahaan menjadi tidak objektif sehingga terjadi kesalahan oleh pengguna informasi dalam menentukan keputusan (Arista et al., 2015). Kejahatan ekonomi yang terus meningkat mengakibatkan para pemangku kepentingan menganggap kecurangan akuntansi menjadi suatu masalah yang sangat serius dalam organisasi (Mangala dan Kumari, 2017). Perbuatan yang merahasiakan informasi sebenarnya atau tidak mengungkapkan informasi dengan tujuan untuk memperdaya pengguna laporan keuangan menjadi salah satu bentuk dari kecurangan yang mungkin dilakukan (Lestari dan Supadmi, 2017). Dampak dari adanya kecurangan akuntansi yaitu berkurangnya kepercayaan pengguna laporan keuangan pada data laporan keuangan yang disajikan untuk publik serta penurunan efisiensi kerja pada perusahaan dan kebangkrutan (Ozcan, 2016). Biasanya ketika kecurangan akuntansi ditemukan maka kerugian tidak dapat dipulihkan kembali atau kesempatan untuk memulihkan jumlah kerugian seperti semula sangatlah tipis (Abdullahi dan Mansor, 2015). Salah satu cara yang dapat digunakan untuk mendeteksi kecurangan akuntansi adalah dengan membandingkan bagaimana persepsi karyawan tentang efektivitas pengendalian perusahaan (Hunziker, 2017; $\mathrm{Vu}, 2016)$. Pendeteksian kecurangan akuntansi dapat pula dilakukan dengan membandingkan antara satu organisasi yang menerapkan program whistleblowing dengan organisasi lain yang tidak menerapkannya (Tunley et al., 2018).

Lembaga keuangan dikatakan sebagai suatu instansi yang memiliki kemungkinan paling besar untuk mengalami kecurangan akuntansi (Putra dan Latrini, 2018). Lembaga Perkreditan Desa (LPD) sebagai salah satu lembaga keuangan di Provinsi Bali yang dibangun dengan tujuan untuk membantu meningkatkan kesejahteraan masyarakat juga turut mengalami kasus-kasus kecurangan akuntansi. LPD ini diharapkan dapat menjadi suatu lembaga yang dapat bersaing dengan lembaga perbankan lainnya namun dengan tetap mempertahankan budaya Bali.

Kasus kecurangan akuntansi sudah terjadi di beberapa LPD di Kabupaten Badung. Kecamatan Mengwi sebagai kecamatan dengan LPD terbanyak juga mengalami kasus serupa, yaitu di LPD Kapal. Kasus ini bahkan sudah diselidiki sejak tahun 2016 yang berawal dari kecurigaan nasabah yang tidak dapat menarik uangnya di LPD tersebut. Berdasarkan penyelidikan Polda Bali, ditemukan bahwa telah terjadi tindak pidana korupsi hingga mencapai miliaran rupiah, yang mana jumlah ini berasal dari hasil audit akuntan publik yang disewa oleh Polda untuk mengaudit LPD Kapal dari tahun 2000-2016. Kurangnya pembinaan dan pemantauan kepada operasional LPD menjadi penyebab utama terjadinya hal tersebut. Mulai dari SDM yang kurang berkualitas dan jarang dilakukannya rotasi kerja sehingga seseorang berada dalam posisi yang sama bertahun-tahun. Berbedanya kondisi yang ada di 
lapangan dengan pencatatan yang dilakukan pada LPD juga menjadi salah satu penyebabnya (NusaBali, 2019).

Kecurangan akuntansi dapat disebabkan oleh tiga faktor yang pertama kali dicetuskan oleh Donald R. Cressey pada tahun 1953 yang disebut dengan konsep segitiga kecurangan atau fraud triangle theory (Cressey, 1953). Tiga faktor inilah yang dapat dikatakan menjadi pemicu terjadinya kecurangan, yang terdiri dari tekanan, kesempatan dan rasionalisasi (Tuanakotta, 2010: 206). Tekanan merupakan insentif untuk bertindak dalam berbagai cara atau metode tertentu (Huang et al., 2017). Tuntutan gaya hidup dan adanya kesulitan dalam masalah keuangan serta ketidakpuasan karyawan pada organisasi juga dapat pula menjadi penyebabnya adanya tekanan (Wirakusuma dan Setiawan, 2019). Kesempatan yang semakin leluasa untuk melakukan kecurangan dalam organisasi juga dapat mengakibatkan kemungkinan terjadinya kecurangan berulang kali atau semakin besar (Donelson et al., 2017). Menurut Kumar et al., (2018) untuk mengurangi faktor kesempatan ini maka penting untuk meningkatkan kemungkinan mendeteksi kecurangan serta penegakan hukum. Rasionalisasi merupakan suatu sikap atau karakter yang dimiliki oleh seseorang yang merasionalkan segala perbuatannya.

Individu yang senantiasa menanamkan moralitas yang tinggi dalam dirinya tentu menjadi salah satu bentuk cara untuk mencegah terjadinya kecurangan akuntansi (Dewi et al., 2017). Moralitas adalah bagaimana suatu moral, asas serta nilai yang berlaku dalam masyarakat mengatur hal-hal terkait dengan baik atau buruknya perbuatan yang dilakukan (Junia, 2016). Kehidupan bermasyarakat tentunya juga memiliki aturan yang mengatur apa yang dapat dilakukan oleh seseorang serta apa yang benar dan salah dalam perbuatan seseorang, selain itu apakah hal tersebut bermanfaat bagi masyarakat yang dalam hal ini berkaitan erat dengan moralitas (Sorunke et al, 2014).

Faktor lain yang juga turut memengaruhi kecurangan akuntansi yaitu komitmen organisasi yang mengacu pada ikatan antara seorang pekerja dengan organisasi tempatnya bekerja yang terkait dengan loyalitas pada perusahaan (Lambert et al., 2013). Berdasarkan hal tersebut maka komitmen organisasi berkaitan dengan keinginan dari karyawan suatu instansi untuk terus bekerja dalam instansi tersebut atau terus mempertahankan keanggotaannya serta ingin melakukan hal-hal yang dapat membantu instansi dalam mencapai tujuannya.

Kompensasi yang diberikan oleh perusahaan juga turut menjadi faktor yang memengaruhi terjadinya kecurangan akuntansi. Menurut Virmayani et al. (2017) kesesuaian kompensasi merupakan suatu rasa puas akan hasil yang diberikan oleh perusahaan kepada pekerjanya atau imbalan yang setimpal dengan pekerjaan yang dilakukan baik berupa pemberian gaji atau upah. Pemberian kompensasi juga menjadi suatu kesempatan bagi perusahaan untuk memperoleh karyawan yang berkualitas sehingga dapat dipertahankan oleh perusahaan.

Penelitian ini dilakukan dengan tujuan untuk menguji pengaruh moralitas individu, komitmen organisasi dan kesesuaian kompensasi pada kecurangan akuntansi di LPD se-Kecamatan Mengwi. Penelitian ini juga dapat memberikan kontribusi positif bagi LPD se-Kecamatan Mengwi baik secara langsung maupun tidak langsung khususnya untuk badan pengawas, pengurus 
dan accounting. Bagi peneliti selanjutnya, penelitian ini dapat menjadi bahan rujukan dan acuan dalam menambah informasi terkait penelitian yang sejenis.

Fraud triangle theory (Cressey, 1953) menjelaskan bahwa terdapat tiga faktor yang dapat memicu terjadinya kecurangan akuntansi. Pentingnya bagi suatu instansi untuk meminimalisir adanya kecurangan, baik itu dengan pemberian kompensasi yang sesuai mengingat banyaknya tekanan atau kebutuhan yang dimiliki masing-masing individu serta meningkatkan komitmen organisasi setiap individu sehingga meskipun terdapat kesempatan yang terbuka lebar untuk melakukan kecurangan maka tidak akan mampu memengaruhi seseorang untuk berbuat curang. Individu yang memiliki moralitas yang tinggi akan kecil kemungkinannya untuk mencari suatu pembenaran untuk berbuat curang. Hal ini merupakan suatu faktor yang terkait erat dengan rasionalisasi.

Berdasarkan teori perkembangan moral (Kohlberg, 1982) dijelaskan bahwa penalaran moral dibagi menjadi tiga tingkatan, yaitu prakonvensional, konvensional dan pasca-konvensional. Individu pada tingkatan prakonvensional cenderungmementingkan diri sendiri dan menganggap aturan-aturan yang memiliki manfaat bagi diri sendiri merupakan hal yang baik sedangkan yang tidak bermanfaat adalah hal buruk (Zhang dan Zhao, 2017). Pada tahap konvensional perbuatan seseorang akan dikatakan baik jika sesuai dengan harapan dari entitas atau kelompok sebaya dilingkungannya. Pascakonvensional merupakan tingkatan tertinggi dimana individu cenderung untuk menggunakan hati nuraninya dalam berbuat meskipun belum tentu hal tersebut menguntungkan dirinya (Yanti et al., 2017). Teori ini digunakan pada penelitian ini karena mampu menjelaskan pada tingkatan atau tahapan moral manakah individu cenderung untuk melakukan kecurangan akuntansi.

Berdasarkan teori penetapan tujuan yang ditemukan oleh Locke (1968) dapat dijelaskan bahwa suatu komitmen akan diperoleh ketika tujuan telah ditetapkan, selain itu komitmen akan terbentuk ketika seseorang memiliki lokus pengendalian internal. Teori ini digunakan dalam penelitian ini karena komitmen organisasi merupakan suatu faktor yang menjadi salah satu penentu tercapainya tujuan organisasi. Hal ini menunjukkan tingkat komitmen organisasi yang tinggi akan membuat seorang karyawan melakukan hal-hal yang memajukan organisasi dan mengurangi kemungkinan adanya tindakan yang menyimpang, salah satunya yaitu kecurangan akuntansi sehingga dapat dikatakan peluang terjadinya kecurangan akuntansi menjadi semakin kecil.

Salah satu teori motivasi yaitu teori harapan (Vroom, 1964) menjelaskan bahwa seseorang akan bertindak berdasarkan apa yang diharapkan dan akan memperoleh hasil yang sesuai dengan kebutuhan individu tersebut. Teori ini juga menjelaskan bahwa dengan adanya imbalan maka seseorang akan dapat termotivasi sampai pada tingkatan tertentu yang dianggap mampu untuk memenuhi tujuan pribadi dari individu tersebut. Teori harapan digunakan dalam penelitian ini karena teori ini mampu menjelaskan bagaimana seorang individu termotivasi untuk memenuhi kebutuhan hidup yang menjadi tujuannya dengan melakukan usaha yang lebih keras demi mendapatkan imbalan yang sesuai dengan kinerjanya sehingga pemberian kompensasi yang sesuai secara tidak langsung dapat meminimalisir kecurangan akuntansi. 
Seseorang yang memiliki kemampuan yang ahli di bidang tata kelola keuangan namun jika tidak memiliki moralitas maka hal tersebut dapat disalahgunakan (Atmadja dan Saputra, 2017). Fraud triangle theory (Cressey, 1953) menjelaskan bahwaindividu yang bermoral rendah akan melakukan rasionalisasi atau mencari pembenaran atas perbuatan yang dilakukan meskipun perbuatan tersebut merupakan perbuatan yang menyimpang. Teori perkembangan moral (Kohlberg, 1982) juga menjelaskan bahwa penalaran moral menjadi suatu dasar dalam melakukan perbuatan sehingga tergantung pada tingkatan moral manakah yang dimiliki oleh individu. Penelitian sebelumnya yaitu Fahmi et al., (2017) dan Eliza (2015) menemukan bahwa moralitas idividu berpengaruh negatif pada kecurangan akuntansi. Hal serupa juga ditemukan oleh Udayani dan Sari (2017) yaitu moralitas individu berperngaruh negatif terhadap kecurangan akuntansi pada Villa di Kawasan Umalas. Semakin tinggi tingkat moralitas individu makaakan menyebabkan semakin kecil kemungkinan seseorang untuk melakukan kecurangan akuntansi. Berdasarkan uraian tersebut, maka hipotesis dalam penelitian ini yaitu:

$\mathrm{H}_{1}$ : Moralitas individu berpengaruh negatif pada kecurangan akuntansi.

Komitmen dari karyawan sangat penting untuk organisasi karena minat, tujuan dan kebutuhan karyawan harus sesuai dengan kepentingan organisasi dalam rangka untuk memperoleh karyawan yang kompeten dan berkualitas (Devece et al., 2015). Fraud triangle theory (Cressey, 1953) menjelaskan bahwa salah satu faktor pemicu terjadinya kecurangan akuntansi adalah faktor kesempatan. Adanya kesempatan yang terbuka lebar dalam melakukan kecurangan akuntansi tidak akan mampu memengaruhi seseorang yang memiliki tingkat komitmen organisasi yang tinggi. Teori penetapan tujuan (Locke, 1968) juga menjelaskan bahwa seseorang tentu memiliki suatu tujuan ketika berada dalam organisasi. Tujuan inilah yang kemudian menjadi suatu awal mula terbentuknya komitmen karyawan terhadap organisasi. Tingginya tingkat komitmen organisasi yang dimiliki oleh karyawan dapat meminimalisir adanya perbuatan yang menyimpang. Penelitian Virmayani et al. (2017) dan Widiutami et al. (2017) menemukan bahwa komitmen organisasi berpengaruh negatif pada kecurangan akuntansi. Berdasarkan hal tersebut maka semakin tinggi komitmen seseorang terhadap organisasi, semakin kecil pula kemungkinannya untuk melakukan perbuatan yang merugikan perusahaan seperti kecurangan akuntansi. Hipotesis yang dapat dikembangkan dari uraian tersebut yaitu:

$\mathrm{H}_{2}$ : Komitmen organisasi berpengaruh negatif pada kecurangan akuntansi.

Kesesuaian kompensasi merupakan imbalan yang diberikan perusahaan kepada pekerjanya sesuai dengan apa yang telah dilakukan (Arista et al., 2015). Teori Fraud Triangle (Cressey, 1953) menjelaskan bahwa faktor tekanan juga memengaruhi terjadinya kecurangan akuntansi. Faktor tekanan ini dapat berasal dari tekanan finansial, tekanan jabatan atau tekanan dari pimpinan. Seseorang yang mengalami tekanan lebih memungkinkan untuk melakukan kecurangan, apalagi hal tersebut menyangkut tekanan finansial sehingga diperlukan pemberian kompensasi yang sesuai dengan beban kerja. Salah satu teori motivasi yaitu teori harapan (Vroom, 1964) menjelaskan bahwa dengan adanya kebutuhan individu maka dapat menjadi suatu motivasi dalam bekerja serta terdapat pula 
imbalan yang diharapkan dari apa yang dikerjakan, oleh sebab itupemberian kompensasi yang sesuai dapat meningkatkan motivasi seseorang untuk meningkatkan kinerjanya sesuai dengan aturan yang berlaku sehingga kecurangan akuntansi dapat diminimalisir.Hasil penelitian Conyon dan $\mathrm{He}$ (2016), Farandy et al. (2017) dan Chandra dan Ikhsan (2015) memperoleh hasil yaitu terdapat pengaruh negatif pada kecurangan akuntansi. Hal ini menjelaskan bahwa semakin sesuai kompensasi yang diberikan, maka semakin kecil kemungkinan individu tersebut melakukan kecurangan akuntansi. Berdasarkan pertimbangan pemaparan diatas maka hipotesis penelitian yang dapat dirumuskan yaitu:

$\mathrm{H}_{3}$ : Kesesuaian kompensasi berpengaruh negatif pada kecurangan akuntansi.

\section{METODE PENELITIAN}

Penelitian ini menggunakan pendekatan kuantitatif yang berbentuk asosiatif, yaitu suatu penelitian yang memiliki tujuan untuk mengetahui apakah terdapat hubungan sebab-akibat. Penelitian ini dilakukan pada LPD se-Kecamatan Mengwi sebab LPD pada wilayah Kecamatan Mengwi memiliki jumlah yang paling banyak yaitu 38 LPD jika dibandingkan dengan kecamatan lainnya di Kabupaten Badung. Obyek penelitian ini adalah kecurangan akuntansi pada LPD se-Kecamatan Mengwi, yang akan dipengaruhi oleh variabel moralitas individu, komitmen organisasi dan kesesuaian kompensasi.

Populasi penelitian ini yakni seluruh pengelola LPD se-Kecamatan Mengwi yang meliputi badan pengawas, pengurus LPD dan karyawan sehingga populasi penelitian ini berjumlah 423orang. Metode penentuan sampel yang digunakan yaitu purposive sampling. Kriteria yang digunakan dalam menentukan sampel dalam penelitian ini yaitu badan pengawas, pengurus (kepala LPD, tata usaha, bendahara) dan accounting pada LPD se-Kecamatan Mengwi yang masih aktif dan terdaftar serta sudah bekerja minimal 2 tahun pada LPD se-Kecamatan Mengwi. Berdasarkan kriteria tersebut maka responden yang menjadi sampel dalam penelitian ini berjumlah 205 orang.

Variabel moralitas individu diukur dengan menggunakan indikator berupa tingkat penalaran moral sesuai dengan Teori Perkembangan Moral Kohlberg yang terdiri dari prakonvensional yaitu memandang kepentingan pribadi sebagai hal yang utama; konvensional yaitu adanya harapan akan kepercayaan dari teman atau keluarga serta berkontribusi untuk instansi; dan pasca-konvensional yang lebih memerhatikan kepentingan orang lain. Dalam mengukur variabel moralitas individu, peneliti menggunakan sebuah kasus dilema etika serta menggunakan instrumen yang terdiri dari 6 buah pernyataan yang dimodifikasi dari penelitian Damayanti (2016).

Indikator dalam mengukur variabel komitmen organisasi ini yaitu berdasarkan jenis komitmen atau tujuan yang dimiliki seseorang dalam organisasi, diantaranya komitmen afektif yang berupa keterlibatan emosional dan perasaan cinta pada organisasi; komitmen berkelanjutan berupa persepsi terhadap biaya dan risiko ketika meninggalkan organisasi; dan komitmen normatif yaitu perasaan loyalitas dan tanggung jawab pada organisasi. Penelitian ini memodifikasi pernyataan kuesioner dari penelitian Limawan dan Mimba (2016) dengan 9 buah pernyataan. 
Kesesuaian kompensasi ini diukur menggunakan indikator yang berdasarkan pada pemberian kompensasi dan motivasi yang diberikan perusahaan kepada karyawan, diantaranya kelayakan gaji; pemberian insentif; pemberian tunjangan; dan fasilitas kerja. Pernyataan kuesioner yang digunakan dalam penelitian ini dimodifikasi dari penelitian Sari (2014) dengan 6 item pernyataan serta untuk kritera pemberian skor dimodifikasi dengan menggunakan skala likert 1-4.

Variabel kecurangan akuntansi diukur dengan indikator berupa jenisjenis kecurangan, yaitu manipulasi; penyajian yang salah atau penghilangan peristiwa; salah menerapkan prinsip akuntansi secara sengaja; penyajian laporan keuangan yang salah akibat penyalahgunaan atau penggelapan terhadap aktiva; dan penyajian laporan keuangan yang salah akibat perlakuan yang tidak semestinya terhadap aktiva dan disertai dengan catatan dan dokumen palsu. Peneliti menggunakan pernyataan kuesioner yang dimodifikasi dari penelitian Shintadevi (2015) dengan 14 item pernyataan.

Metode pengumpulan data yang digunakan dalam penelitian ini berupa kuesioner yang dinilai dengan menggunakan skala likert 1-4. Kuesioner yang digunakan pada penelitian ini berjumlah 194 kuesioner dari jumlah seluruh sampel yaiu 205 sampel. Instrumen pada penelitian ini diuji dengan menggunakan dua uji diantaranya yaitu uji validitas dan uji reliabilitas dengan tujuan untuk mengukur bagaimana kemampuan dari kuesioner untuk menampilkan data yang akurat. Teknik analisis data yang digunakan yaitu analisis regresi linier berganda.

\section{HASIL DAN PEMBAHASAN}

Uji validitas adalah suatu uji untuk mengukur ketepatan alat ukur penelitian dalam mengukur suatu hal atau dengan kata lain valid atau tidaknya kuesioner. Hasil uji validitas menunjukkan bahwa instrumen penelitian memiliki nilai pearson product moment atau koefisien korelasi yang positif dan lebih besar dari 0,30 . Hal ini menunjukkan setiap item pernyataan memiliki nilai $r$ hitung yang lebih besar dari 0,30 sehingga seluruh pernyataan yang digunakan valid.

\section{Tabel 1. Hasil Uji Reliabilitas}

\begin{tabular}{lllll}
\hline No & \multicolumn{1}{c}{ Variabel Penelitian } & $\begin{array}{c}\text { Cronbach's } \\
\text { Alpha }\end{array}$ & $\begin{array}{c}\text { Syarat } \\
\text { Cronbach's } \\
\text { Alpha }\end{array}$ & Keterangan \\
\hline 1 & Moralitas Individu $\left(\mathrm{X}_{1}\right)$ & 0,779 & 0,600 & Reliabel \\
2 & Komitmen Organisasi $\left(\mathrm{X}_{2}\right)$ & 0,711 & 0,600 & Reliabel \\
3 & Kesesuaian Kompensasi $\left(\mathrm{X}_{3}\right)$ & 0,857 & 0,600 & Reliabel \\
4 & Kecurangan Akuntansi $(\mathrm{Y})$ & 0,885 & 0,600 & Reliabel \\
\hline
\end{tabular}

Sumber: Data Penelitian, 2019

Uji reliabilitas dilakukan untuk mengukur konsistensi instrumen. Kuesioner dikatakan reliabel apabila jawaban yang diberikan oleh responden konsisten dari waktu ke waktu serta dapat dipercaya. Hasil uji reliabilitas pada Tabel 1. menunjukkan bahwa nilai Cronbanch's Alpha masing-masing variabel pada kuesioner lebih besar dari 0,60. Kondisi ini menunjukkan bahwa pernyataan pada kuesioner ini reliabel dan layak untuk dianalisis lebih lanjut. 
Tabel 2. Hasil Analisis Statistik Deskriptif

\begin{tabular}{lccccc}
\hline \multicolumn{1}{c}{ Variabel } & $\mathrm{N}$ & Min. & Max. & Mean & Std. Deviasi \\
\hline Moralitas Individu $\left(\mathrm{X}_{1}\right)$ & 194 & 12 & 23 & 18,74 & 2,715 \\
Komitmen Organisasi $\left(\mathrm{X}_{2}\right)$ & 194 & 17 & 35 & 26,85 & 3,296 \\
Kesesuaian Kompensasi $\left(\mathrm{X}_{3}\right)$ & 194 & 14 & 40 & 30,34 & 4,106 \\
Kecurangan Akuntansi $(\mathrm{Y})$ & 194 & 14 & 38 & 21,08 & 4,930 \\
\hline
\end{tabular}

Sumber: Data Penelitian, 2019

Berdasarkan Tabel 2. maka dapat dilihat nilai minimum dari variabel moralitas individu $\left(X_{1}\right)$ adalah 12. Nilai maksimumnya adalah 23 dan nilai ratarata dari variabel moralitas individu $\left(\mathrm{X}_{1}\right)$ yaitu 18,74 . Variabel moralitas individu memiliki nilai standar deviasi sebesar 2,715. Hal ini berarti terjadi penyimpangan nilai moralitas individu terhadap nilai rata-rata sebesar 2,715.

Variabel komitmen organisasi $\left(\mathrm{X}_{2}\right)$ memiliki nilai minimum yaitu 17 dan nilai maksimumnya adalah 35 . Nilai rata-rata variabel komitmen organisasi $\left(X_{2}\right)$ yaitu 26,85. Komitmen organisasi memiliki nilai standar deviasi sebesar 3,296. Hal ini menjelaskan bahwa terjadi penyimpangan nilai komitmen organisasi terhadap nilai rata-rata sebesar 3,296.

Tabel 2. menunjukkan bahwa variabel kesesuaian kompensasi $\left(X_{3}\right)$ memiliki nilai minimum sebesar 14 dan nilai maksimumnya adalah 40. Nilai rata-rata variabel kesesuaian kompensasi $\left(X_{3}\right)$ yaitu 30,34. Variabel kesesuaian kompensasi $\left(X_{3}\right)$ memiliki nilai standar deviasi sebesar 4,106. Hal tersebut menjelaskan bahwa terjadi penyimpangan nilai kesesuaian kompensasi terhadap nilai rata-rata sebesar 4,106

Berdasarkan Tabel 2. diperoleh bahwa variabel kecurangan akuntansi (Y) memiliki nilai minimum yaitu 14 sedangkan nilai maksimumnya yaitu 38. Variabel kecurangan akuntansi (Y) memiliki nilai rata-rata yaitu 21,08. Nilai standar deviasi yang dimiliki yaitu sebesar 4,930. Hal ini menjelaskan terjadi penyimpangan dari nilai kecurangan akuntansi terhadap rata-rata sebesar 4,930.

Tabel 3. Hasil Uji Normalitas

\begin{tabular}{ll}
\hline $\mathrm{N}$ & Unstandardized Residual \\
Kolmogorov-Smirnov (K-S) & 194 \\
Asymp. Sig. (2-tailed) & 0,053 \\
\hline
\end{tabular}

Sumber: Data Penelitian, 2019

Hasil uji normalitas pada Tabel 3. menunjukkan bahwa nilai KolmogorovSmirnov(K-S) sebesar 0,053 dengan nilai Asymp. Sig (2-tailed) sebesar 0,200 yang lebih besar dari ${ }^{\alpha}=0,05$. Hal tersebut menunjukkan bahwa model persamaan regresi telah terdistribusi normal. 
Tabel 4. Hasil Uji Multikolinearitas

\begin{tabular}{llll}
\hline \multirow{2}{*}{ Variabel } & \multicolumn{2}{c}{ Collinearity Statistics } & Keterangan \\
\cline { 2 - 3 } & Tolerance & VIF & \\
\hline Moralitas Individu $\left(\mathrm{X}_{1}\right)$ & 0,978 & 1,022 & Bebas Multikolinearitas \\
Komitmen Organisasi $\left(\mathrm{X}_{2}\right)$ & 0,821 & 1,218 & Bebas Multikolinearitas \\
Kesesuaian Kompensasi $\left(\mathrm{X}_{3}\right)$ & 0,833 & 1,201 & Bebas Multikolinearitas \\
\hline
\end{tabular}

Sumber: Data Penelitian, 2019

Tabel 4. menunjukkan bahwa masing-masing variabel bebas memiliki nilai tolerance lebih besar dari 10 persen atau 0,10 serta nilai VIF berada dibawah 10. Hal tersebut menunjukkan bahwa tidak terjadi multikolinearitas pada model persamaan regresi yang diteliti.

Tabel 5. Hasil Uji Heteroskedastisitas

\begin{tabular}{lll}
\hline \multicolumn{1}{c}{ Variabel } & \multicolumn{1}{c}{ Sig. } & Keterangan \\
\hline Moralitas Individu $\left(\mathrm{X}_{1}\right)$ & 0,134 & Bebas Heteroskedastisitas \\
Komitmen Organisasi $\left(\mathrm{X}_{2}\right)$ & 0,288 & Bebas Heteroskedastisitas \\
Kesesuaian Kompensasi $\left(\mathrm{X}_{3}\right)$ & 0,132 & Bebas Heteroskedastisitas \\
\hline
\end{tabular}

Sumber: Data Penelitian, 2019

Tabel 5. menunjukkan bahwa nilai signifikansi dari masing-masing variabel lebih besar dari 0,05 . Hal tersebut menunjukkan bahwa seluruh variabel bebas tidak mengandung gejala heteroskedastisitas. Ini menunjukkan bahwa tidak ada pengaruh antara variabel bebas terhadap absolute residual.

Tabel 6. Hasil Analisis Regresi Linear Berganda

\begin{tabular}{clcccc}
\hline Model & \multicolumn{2}{c}{$\begin{array}{c}\text { Unstandardized } \\
\text { Coefficients }\end{array}$} & $\begin{array}{c}\text { Standardized } \\
\text { Coefficients }\end{array}$ & T & Sig. \\
\cline { 2 - 4 } & B & Std. Error & Beta & & \\
\hline (Constant) & 53,919 & 3,088 & & 17,463 & 0,000 \\
X1 & $-0,605$ & 0,105 & $-0,333$ & $-5,753$ & 0,000 \\
X2 & $-0,468$ & 0,095 & $-0,313$ & $-4,943$ & 0,000 \\
X3 & $-0,294$ & 0,075 & $-0,245$ & $-3,902$ & 0,000 \\
Adjusted R Square & 0,366 & & & \\
F & 38,063 & & & \\
Sig. & 0,000 & & & \\
\hline
\end{tabular}

Sumber: Data Penelitian, 2019

Berdasarkan Tabel 6. nilai konstanta $\left({ }^{\alpha}\right)$ sebesar 53,919 menunjukkan bahwa apabila nilai moralitas individu $\left(X_{1}\right)$, komitmen organisasi $\left(X_{2}\right)$ dan kesesuaian kompensasi $\left(X_{3}\right)$ sama dengan nol, maka nilai kecurangan akuntansi (Y) adalah sebesar 53,919. Koefisien regresi $\left(\beta_{1}\right)$ untuk variabel moralitas individu bernilai $-0,605$. Nilai ini memiliki hubungan negatif terhadap kecurangan akuntansi yang artinya apabila moralitas individu meningkat, maka kecurangan akuntansi akan mengalami penurunan sebesar 0,605 dengan asumsi variabel bebas lainnya konstan. Koefisien regresi $\left(\beta_{2}\right)$ untuk variabel komitmen organisasi bernilai $-0,468$. Ini berarti bahwa jika komitmen organisasi meningkat maka kecurangan akuntansi akan mengalami penurunan sebesar 0,468 dengan asumsi variabel bebas lainnya konstan. Koefisien regresi $\left(\beta_{3}\right)$ untuk variabel kesesuaian kompensasi memiliki nilai -0,294. Koefisien regresi ini memiliki nilai negatif yang artinya apabila kesesuaian kompensasi meningkat maka 
kecurangan akuntansi akan mengalami penurunan sebesar 0,294 dengan asumsi variabel bebas lainnya konstan.

Uji koefisien determinasi digunakan untuk mengukur kemampuan variabel independen dalam menjelaskan variasi dari variabel dependen. Hasil uji koefisien determinasi penelitian ini dapat dilihat pada Tabel 6. yang menunjukkan bahwa nilai adjusted $R^{2}$ adalah 0,366. Hal ini berarti bahwa 36,6 persen variasi kecurangan akuntansi dipengaruhi oleh variasi moralitas individu, komitmen organisasi dan kesesuaian kompensasi. Sisanya sebesar 63,4 persen dijelaskan oleh faktor lain yang tidak dimasukkan ke dalam model.

Uji kelayakan model atau Uji F merupakan suatu uji yang dilakukan untuk menguji apakah semua variabel independen mempunyai pengaruh terhadap variabel dependen secara bersama-sama serta untuk mengidentifikasi model regresi yang diteliti layak atau tidak. Hasil dari uji regresi dinyatakan layak jika nilai signifikansi uji $\mathrm{F}$ kurang dari 0,05 . Hasil uji $\mathrm{F}$ penelitian ini dapat dilihat pada Tabel 6. yaitu nilai $\mathrm{F}$ hitung sebesar 38,063 dan nilai sig. F sebesar 0,00 yang lebih kecil dari 0,05 . Hal tersebut menjelaskan bahwa model persamaan ini layak digunakan serta ketiga variabel bebas yaitu moralitas individu, komitmen organisasi dan kesesuaian kompensasi dapat memprediksi atau menjelaskan kecurangan akuntansi.

Uji t dilakukan untuk menguji signifikansi secara individual dari variabel independen terhadap variabel dependen. Apabila nilai signifikansi $\leq 0,05$ maka $\mathrm{H}_{0}$ ditolak dan $\mathrm{H}_{1}$ diterima. Pada Tabel 6. diperoleh nilai signifikansi uji t dari variabel moralitas individu yaitu 0,00 yang lebih kecil dari 0,05 dengan nilai koefisien beta $-0,605$. Hal ini menunjukkan bahwa moralitas individu berpengaruh negatif pada kecurangan akuntansi. Ini berarti hipotesis pertama pada penelitian ini diterima. Moralitas yang tinggi membuat seseorang cenderung untuk melakukan perbuatan yang benar. Hal ini berkaitan dengan rasionalisasi pada fraud triangle theory (Cressey, 1953), dimana jika seseorang bermoral rendah maka lebih cenderung merasionalisasi pembenaran akan tindakan yang dilakukannya meskipun hal tersebut salah, begitu pula sebaliknya. Sesuai dengan teori perkembangan moral (Kohlberg, 1982) perilaku yang dimiliki oleh setiap individu dipengaruhi oleh tingkat penalaran moral yang dimilikinya serta penalaran moral inilah yang digunakan sebagai suatu dasar dari perilaku etis. Apabila moralitas individu berada pada tingkatan moralitas yang paling tinggi maka individu tersebut akan lebih mementingkan kepentingan bersama daripada kepentingan pribadi sehingga tentu individu tersebut akan mematuhi peraturan yang berlaku untuk menghindari kecurangan akuntansi. Semakin tinggi tingkat moralitas yang dimiliki oleh individu yang bekerja pada LPD se-Kecamatan Mengwi maka dapat mengurangi terjadinya kecurangan akuntansi. Hasil penelitian ini mendukung penelitian-penelitian sebelumnya diantaranya Fahmi et al., (2017) dan Eliza (2015) yang menemukan bahwa moralitas individu berpengaruh negatif pada kecurangan akuntansi. Putra dan Latrini (2018) juga memeroleh hasil penelitian yang serupa yaitu moralitas berpengaruh negatif pada kecurangan akuntansi di LPD se-Kabupaten Gianyar.

Berdasarkan Tabel 6. diperoleh nilai signifikansi uji $t$ dari variabel komitmen organisasi yaitu 0,00 yang lebih kecil dari 0,05 dengan nilai koefisien 
beta $-0,468$. Hal ini menunjukkan bahwa komitmen organisasi berpengaruh negatif dan signifikan pada kecurangan akuntansi. Ini berarti hipotesis kedua pada penelitian ini diterima. Tingginya komitmen organisasi yang dimiliki menjadi suatu hal penting dalam mencapai tujuan organisasi. Hasil penelitian ini mendukung fraud triangle theory (Cressey, 1953) yang menjelaskan terdapatnya kesempatan yang lebar dalam melakukan kecurangan juga menjadi faktor pemicu. Seseorang dengan komitmen yang tinggi meskipun diberikan kesempatan untuk berbuat yang merugikan organisasi, maka hal tersebut tidak akandilakukan. Hasil penelitian ini juga mendukung teori penetapan tujuan (Locke, 1968) yang menjelaskan bahwa terdapat suatu ikatan antara tujuan yang telah ditentukan oleh instansi dengan kinerja yang akan dihasilkan oleh individu. Tujuan inilah yang akan memengaruhi tingkat komitmen organisasi yang dimiliki. Komitmen organisasi yang tinggi akan membuat seseorang berusaha untuk mewujudkan tujuan organisasi karena memang ingin menjadi anggota organisasi dan menganggap dirinya sebagai bagian dari organisasi serta menghindari kecurangan akuntansi. Hasil penelitian ini mendukung hasil-hasil penelitian sebelumnya yaitu penelitian Virmayani et al. (2017) yang menemukan bahwa komitmen organisasi berpengaruh negatif pada kecurangan akuntansi. Hal tersebut juga didukung oleh Widiutami et al. (2017) yang memperoleh hasil serupa yaitu komitmen organisasi berpengaruh negatif pada kecurangan akuntansi.

Tabel 6. menunjukkan bahwa nilai signifikansi uji $t$ dari variabel kesesuaian kompensasi yaitu 0,00 yang lebih kecil dari 0,05 dengan nilai koefisien beta yaitu -0,294. Hal ini mengindikasikan bahwa kesesuaian kompensasi berpengaruh negatif pada kecurangan akuntansi. Ini berarti hipotesis ketiga pada penelitian ini diterima. Kompensasi yang sesuai terhadap beban kerja yang menjadi tanggungjawab pegawai dapat menumbuhkan rasa loyalitas pegawai sehingga pegawai secara tidak langsung menghindari perilaku yang menyimpang. Hasil penelitian ini mendukung teori Fraud Triangle (Cressey, 1953) yang menjelaskan bahwa terdapat faktor tekanan baik berupa finansial atau non finansial yang mungkin dirasakan dapat menjadi pemicu untuk berbuat curang sehingga akibatnya diperlukan sistem kompensasi yang seimbang dengan kinerja karyawan agar karyawan merasa puas akan kompensasi yang diberikan perusahaan dan dapat mengurangi tekanan finansial yang mungkin dialami. Hasil penelitian ini juga mendukung salah satu teori motivasi yaitu teori harapan (Vroom, 1964). Teori harapan ini menjelaskan bahwa setiap orang akan melakukan sesuatu atas dasar apa yang diharapkannya serta hasil yang diharapkan tersebut hendaknya dapat memenuhi kebutuhan individunya. Motivasi yang dimiliki individu untuk memenuhi kebutuhan hidupnya juga menjadi salah satu pendorong individu tersebut untuk berusaha mendapatkan hasil yang mampu mencukupi. Pemberian kompensasi yang sesuai dapat membuat individu merasa diperlakukan secara adil sekaligus meningkatkan loyalitas individu terhadap instansi sehingga senantiasa bekerja dengan baik dan menghindari kecurangan akuntansi. Hasil penelitian ini mendukung hasil penelitian sebelumnya yaitu Aji (2018) memeroleh hasil yaitu kesesuaian kompensasi berpengaruh negatif pada kecurangan akuntansi. Farandy et al. 
(2017) dan Chandra dan Ikhsan (2015) juga memperoleh hasil yang serupa yaitu terdapat pengaruh negatif pada kecurangan akuntansi.

\section{SIMPULAN}

Berdasarkan hasil analisis yang dilakukan maka diperoleh simpulan yaitu moralitas individu, komitmen organisasi dan kesesuaian kompensasi berpengaruh negatif pada kecurangan akuntansi. Semakin tinggi moralitas, komitmen organisasi dan kesesuaian kompensasi pada LPD se-Kecamatan Mengwi maka semakin kecil kemungkinan terjadinya kecurangan akuntansi. Peneliti selanjutnya sebaiknya dapat melakukan penelitian di lokasi yang berbeda atau memperluas lokasi penelitian dari Kecamatan menjadi Kabupaten atau di perusahaan swasta dan perbankan, sehingga dapat memperluas penelitian sebelumnya. Peneliti selanjutnya juga dapat menambahkan atau meneliti variabel yang berbeda, mengingat nilai Adjusted $R^{2}$ adalah 0,366 yang menunjukkan bahwa terdapat 63,4 persen faktor lain yang memengaruhi namun tidak dimasukkan ke dalam model.

Saran yang dapat diberikan dari penelitian ini yaitu LPD se-Kecamatan Mengwi dapat memberikan pelatihan dan pengembangan moral pada setiap pegawai agar menghindari dilakukannya perbuatan yang tidak etis dan merugikan instansi serta turut berpartisipasi dalam pengambilan keputusan instansi dan memberikan kompensasi yang adil serta meningkatkan kejelasan peran yang dimiliki karyawan dalam organisasi. Selain itu dengan cara melakukan evaluasi terhadap beban kerja pegawai dan memberikan kejelasan terkait kompensasi yang diperoleh oleh masing-masing pegawai. Peneliti selanjutnya juga dapat menambah jumlah populasi dan sampel yang digunakan dalam penelitian sehingga hasil yang diperoleh lebih menyeluruh dan lengkap.

\section{REFERENSI}

Abdullah, R., \& Mansor, N. (2015). Fraud Triangle Theory and Fraud Diamond Theory . Understanding the Convergent and Divergent For Future Research. International Journal of Academic Research in Accounting, Finance and Management Sciences, 5(4), 38-45. https://doi.org/10.6007/IJARAFMS/v5$3 / 1823$

Aji, S. S. B. (2018). The Determinants Affecting Fraud Trends. Asia Pacific Fraud Journal, 3(1), 21-31. https:// doi.org/10.21532/apfj.001.18.03.01.03

Arista, L. L., Hendra, K., \& Suhendro. (2015). Pengaruh Faktor-Faktor Internal Terhadap Kecenderungan Kecurangan Akuntansi Pada Pt. Pegadaian Persero Surakarta. Jurnal Ekonomika Bisnis, 06(02). https://doi.org/10.22219/jekobisnis.v6i2.2680

Atmadja, A. T., \& Saputra, K. A. K. (2017). Pencegahan Fraud Dalam Pengelolaan Keuangan Desa. Jurnal Ilmiah Akuntansi Dan Bisnis, 12(1), 7-16.

Chandra, D. P., \& Ikhsan, S. (2015). Determinan Terjadinya Kecenderungan Kecurangan Akuntansi (Fraud) Pada Dinas Pemerintah Se Kabupaten Grobogan. Accounting Analysis Journal, 4(3), 1-9.

Conyon, M. J., \& He, L. (2016). Executive Compensation and Corporate Fraud in China. Journal of Business Ethics, 134(4), 669-691. https://doi.org/10.1007/s10551-014-2390-6 
Cressey, D. R. (1953). Other People's Money: A Study in the Social Psychology of Embezzlement. In Free Press. Glencoe, III.

Damayanti, D. N. S. (2016). Pengaruh Pengendalian Internal Dan Moralitas Individu Terhadap Kecurangan Akuntansi. Nominal, Barometer Riset Akuntansi Dan Manajemen, 5(2). https://doi.org/10.21831/nominal.v5i2.11725

Devece, C., Palacios-Marqués, D., \& Alguacil, M. P. (2015). Organizational commitment and its effects on organizational citizenship behavior in a highunemployment environment. Journal of Business Research, 69(5), 1857-1861. https://doi.org/10.1016/j.jbusres.2015.10.069

Dewi, K. T. K., Wahyuni, M. A., \& Herawati, N. T. (2017). Pengaruh Sistem Pengendalian Kas, Implementasi Good Governance, Moralitas Aparatur Pemerintah Daerah, Dan Persepsi Kesesuaian Kompensasi Terhadap Financial Fraud ( Studi Empiris pada SKPD di Kabupaten Buleleng ). EJournal S1 Ak Universitas Pendidikan Ganesha, 7(1).

Donelson, D. C., Ege, M. S., \& McInnis, J. M. (2017). Internal control weaknesses and financial reporting fraud. Auditing A Journal of Practice \& Theory, 36(3), 45-69. https://doi.org/10.2308/ajpt-51608

Eliza, Y. (2015). Pengaruh Moralitas Individu Dan Pengendalian Internal Terhadap Kecenderungan Kecurangan Akuntansi: Studi Eksperimen PadaSKPS di Kota Padang. Jurnal Akuntansi, 4(1), 86-100.

Fahmi, A., Anugerah, R., \& Rasuli, M. (2017). Pengaruh Moralitas Dan Kompensasi Terhadap Kecenderungan Kecurangan Akuntansi (Studi Empiris Pada Organisasi Perangkat Daerah (Opd) Pemerintah Provinsi Riau). Jurnal Ekonomi, 25(3), 1-14.

Farandy, R., Nur, E., \& Yasni, H. (2017). Pengaruh Keefektifan Pengendalian Internal, Kesesuaian Kompensasi, Dan Keadilan Distributif Terhadap Kecenderungan Kecurangan Akuntansi Melalui Kepuasan Kerja Sebagai Variabel( Studi Pada Satuan Kerja Perangkat Daerah Kota Pekanbaru ). JOM Fekon, 4(1), 2340-2354.

Huang, S. Y., Lin, C.-C., Chiu, A.-A., \& Yen, D. C. (2017). Fraud detection using fraud triangle risk factors. Information Systems Frontiers, 19(6), 1343-1356. https://doi.org/10.1007/s10796-016-9647-9

Hunziker, S. (2017). Efficiency of Internal Control: Evidence from Swiss Nonfinancial Companies. Journal of Management and Governance, 21(2), 399-433. https:// doi.org/10.1007/s10997-016-9349-1

Junia, N. (2016). Pengaruh Moralitas Aparat, Kesesuaian Kompensasi, Dan Ketaatan Aturan Akuntansi Terhadap Kecenderungan Kecurangan Akuntansi. JOM Fekon, 3(1), 1623-1637.

Kohlberg, L. (1982). Moral stages and moralization. A cognitive developmental approach. Journal for the Study of Education and Development, 5(18), 33-51. https://doi.org/10.1080/02103702.1982.10821935

Kumar, K., Sukanto, B., \& Hicks, R. (2018). Employee perceptions of organization culture with respect to fraud - where to look and what to look for. Pacific Accounting Review, 30(2), 187-198. https://doi.org/https://doi.org/10.1108/PAR-05-2017-0033

Lambert, E. G., Kelley, T., \& Hogan, N. L. (2013). The Association of Occupational 
Stressors with Different Forms of Organizational Commitment Among Correctional Staff. American Journal of Criminal Justice, 38(3), 480-501. https://doi.org/10.1007/s12103-012-9183-1

Lestari, N. K. L., \& Supadmi, N. L. (2017). Pengaruh Pengendalian Internal, Integritas Dan Asimetri Informasi Pada Kecurangan Akuntansi. E-Jurnal Akuntansi Universitas Udayana, 21(1), 389-417.

Limawan, Y. F., \& Mimba, N. P. S. H. (2016). Pengaruh Komitmen Organisasi, Locus of Control Dan Tekanan Anggaran Waktu Audit Pada Penerimaan Underreporting of Time. E-Jurnal Akuntansi Universitas Udayana, 15(1), 799831.

Locke, E. A. (1968). Toward a theory of task motivation and incentives. Organizational Behavior and Human Performance, 3(2), 157-189. https://doi.org/10.1016/0030-5073(68)90004-4

Mangala, D., \& Kumari, P. (2017). Auditors' Perceptions of the Effectiveness of Fraud Prevention and Detection Methods. Indian Journal of Corporate Governance, 10(2), 118-142. https:/ / doi.org/10.1177/0974686217738683

NusaBali. (2019). Kepala LPD Kapal, Mengwi Dituntut 5 Tahun. Diakses pada 2 Agustus 2019. Retrieved from https://www.nusabali.com/berita/49640/kepala-lpd-kapal-mengwidituntut-5-tahun

Ozcan, A. (2016). Firm Characteristics and Accounting Fraud: A Multivariate Approach (Firma Karakteristikleri ve Muhasebe Hilesi: Çok Değişkenli Yaklaşım). Journal $f$ Accounting, Finance and Auditing Studies, 2(2), 128-144.

Putra, I. P. A. P. E., \& Latrini, M. Y. (2018). Pengaruh Pengendalian Internal, Budaya Organisasi, dan Moralitas pada Kecenderungan Kecurangan (Fraud) di LPD Se-Kabupaten Gianyar. E-Jurnal Akuntansi Universitas Udayana, 25(3), 2155-2184. https://doi.org/https://doi.org/10.24843/EJA.2018.v25.i03.p20

Sari, U. T. (2014). Pengaruh Kompensasi dan Gaya Kepemimpinan terhadap Kinerja Karyawan Melalui Motivasi Kerja Karyawan CV. Terus Jaya Cilacap. Jurnal Manajemen Bisnis Indonesia, 3(III). https:// doi.org/10.22146/jlo.43771

Shintadevi, P. F. (2015). Pengaruh Keefektifan Pengendalian Internal, Ketaatan Aturan Akuntansi dan Kesesuaian Kompensasi terhadap Kecenderungan Kecurangan Akuntansi dengan Perilaku Tidak Etis sebagai Variabel Intervening. Jurnal Nominal, IV(2), 111-126. Retrieved from http:/ /id.portalgaruda.org/ ?ref=browse\&mod=viewarticle\&article=390019

Sorunke, O., Adetoun, O., Musa, A., \& Nathaniel, A. (2014). Ethical Issues in Financial Reporting and Theories that Drive Them; A Discourse. International Journal of Business and Common Market Studies, 11(1 \& 2), 59-69.

Tuanakotta, T. M. (2010). Akuntansi Forensik \& Audit Investigatif. In Edisi 2. Jakarta: Salemba Empat. https:// doi.org/10.1016/j.clay.2015.06.031

Tunley, M., Button, M., Shepherd, D., \& Blackbourn, D. (2018). Preventing occupational corruption: Utilising situational crime prevention techniques and theory to enhance organisational resilience. Security Journal, 31(1), 2152. https:// doi.org/10.1057/s41284-016-0087-5

Udayani, A. A. K. F., \& Sari, M. M. R. (2017). Pengaruh Pengendalian Internal 
Dan Moralitas Individu Pada Kecenderungan Kecurangan Akuntansi. EJurnal Akuntansi Universitas Udayana, 18(3), 1774-1799. https://doi.org/10.24036/20171115

Virmayani, P. C., Sulindawati, N. L. G. E., \& Atmadja, A. T. (2017). Pengaruh Kesesuaian Kompensasi, Asimetri Informasi, Budaya Etis Organisasi dan Komitmen Organisasi Terhadap Kecenderungan Kecurangan (Fraud) Akuntansi Pada Koperasi Simpan Pinjam Se-kecamatan Buleleng. E-Journal SI Ak Universitas Pendidikan Ganesha, 7(1).

Vroom, V. H. (1964). Motivation: A point of view. In Work and motivation.

Vu, H. T. (2016). The Research of Factors Affecting the Effectiveness of Internal Control Systems in Commercial Banks-empirical Evidence in Viet Nam. International Business Research, 9(7), 144-153. https:// doi.org/10.5539/ibr.v9n7p144

Widiutami, N. P. S., Sulindawati, N. L. G. E., \& Atmadja, A. T. (2017). Pengaruh Efektivitas Pengendalian Internal, Ketaatan Aturan Akuntansi, Dan Komitmen Organisasi Terhadap Kecenderungan Kecurangan ( Fraud ) Akuntansi ( Studi Empiris Pada Lembaga Perkreditan Desa di Kabupaten Buleleng ). E-Journal S1 Ak Universitas Pendidikan Ganesha, 7(1).

Wirakusuma, I. G. B., \& Setiawan, P. E. (2019). Pengaruh Pengendalian Internal, Kompetensi dan Locus of Control Pada Kecenderungan Kecurangan Akuntansi. E-Jurnal Akuntansi Universitas Udayana, 26(2), 1545-1569. https:// doi.org/https://doi.org/10.24843/EJA.2019.v26.i02.p26

Yanti, H. B., Hasnawati, Astuti, C. D., \& Kuncara, H. (2017). Kompetensi Moral Dan Intensi Whistleblowing. Jurnal Media Riset Akuntansi, Auditing $\mathcal{E}$ Informasi, 17(2), 131-144. https:// doi.org/10.25105/mraai.v17i2.2074

Zhang, Q., \& Zhao, H. (2017). An Analytical Overview of Kohlberg's Theory of Moral Development in College Moral Education in Mainland China. Open Journal of Social Sciences, 05(08), 151-160. https://doi.org/10.4236/jss.2017.58012 